Der reformierte Schleiermacher 



\section{Der reformierte Schleiermacher}

Gespräche über das reformierte Erbe in seiner Theologie

Herausgegeben von

Anne Käfer unter Mitarbeit von Bastian König 
ISBN 978-3-11-063183-8

e-ISBN (PDF) 978-3-11-063357-3

e-ISBN (EPUB) 978-3-11-063200-2

Library of Congress Control Number: 2019937890

\section{Bibliografische Information der Deutschen Nationalbibliothek}

Die Deutsche Nationalbibliothek verzeichnet diese Publikation in der Deutschen Nationalbibliografie; detaillierte bibliografische Daten sind im Internet über http://dnb.dnb.de abrufbar.

(C) 2019 Walter de Gruyter GmbH, Berlin/Boston

Umschlagabbildung: Ölbild im Gemeinderaum der Evang. Kirchengemeinde in der Friedrichstadt Berlin-Mitte, Foto: Bjela Proßowsky.

Druck und Bindung: $\mathrm{CPI}$ books $\mathrm{GmbH}$, Leck

www.degruyter.com 